DOI: 10.17277/voprosy.2019.02.pp.052-056

\title{
KEY PERFORMANCE INDICATORS AS A TOOL FOR BUILDING AN EFFECTIVE PERSONNEL MOTIVATON SYSTEM
}

\author{
E. S. Mishchenko, M. S. Lukianenko
}

Tambov State Technical University, Tambov, Russia

Reviewed by Doctor of Economics Sciences, Professor N. V. Zlobina

Keywords: key performance indicators; KPI; personnel motivation system; company's strategic goals.

\begin{abstract}
The article considers the problems of companies engaged in the development and implementation of personnel motivation system. The examples of implementing occasional tools of raising the loyalty of staff are given. The term "key performance indicator" (KPI) is defined. The interrelation between the KPI system and company's strategic goals is described. The algorithm of implementing the system of key performance indicators into the company's business-processes is considered. Main advantages and disadvantages of implementing the KPI system are described. Basic stages and principles of implementing the KPI system are given. Main problems which companies face in the process of implementing the KPI system are considered. The peculiarities of forming the personnel motivation system based on using key performance indicators are described. The experience of implementing the KPI system in the pharmacy chain "Viktoriya Region" is considered. Basic stages of implementing the KPI system are given: the identification of the strategic goals; the development of the key performance indicators system for the pharmacy chain as a whole, for the certain pharmacy, for the certain employee; the allocation of professional duties due to KPI; the adjustment of business-processes; the development of a new personnel motivation system; the launch; control and the adjustment of results. The strategic goals of a pharmacy chain "Viktoriya Region" are defined. KPIs of a pharmaceutical business are given. The mechanism of calculating the amount of employee payment is described. The evaluation of the effectiveness of the KPI system is given.
\end{abstract}

Мищенко Елена Сергеевна - доктор экономических наук, проректор по международной деятельности, профессор кафедры «Менеджмент»; Лукьяненко Маргарита Сергеевна - ассистент кафедры «Экономика», e-mail: atamanova.tmb@mail.ru, ТамбГТУ, г. Тамбов, Россия. 
There is no doubt that raising profitability and efficiency is the most important aim of each business entity. Assuredly company efficiency is directly dependent on the personal result of the whole staff. That is why for achieving the above-stated goal company management has to focus efforts on solving the problem of raising the quality of personal employees' results. In turn, these results depend on the existing personnel motivation system. Thus, constructing the appropriate motivation system should become the primary internal company goal.

Nowadays modern companies use a wide variety of both monetary and nonmonetary tools and methods of motivation. For instance, offices of most Tambov IT-companies are provided with leisure-rooms with books, coffeemachines, game consoles and so on. Short breaks during the working day help employees to avoid stress. The same companies form their motivation systems with corporate gym programs, corporate education, business trips to interesting places, joint rest, etc. All the above-stated examples are aimed to raise the loyalty and productivity of employees.

However, providing employees with such incentives requires significant financial investments. Thus, evaluating the effectiveness of these investments is of importance. Measuring qualitative and quantitative indicators of each employee's effectiveness is rather difficult. Nevertheless, nowadays there is a variety of methods which are used for solving this problem. One of them is the system of "key performance indicators".

The Cambridge Dictionary defines key performance indicator (KPI) as one of the most important indicators that show how well an economy, company, project, etc. is doing, or how well an employee is working [1]. KPI can also be defined as a quantitative indicator of achieving some desirable goal.

One of the founders of KPI is the famous American scientist Peter Drucker, whose idea of "management by objectives" implied considering the system of effectiveness' evaluation through the key performance indicators. American companies implemented principles of KPI into business processes decimals ago. As for Russian companies, KPI became widely used about ten years ago.

Implementing the KPI system means identifying indicators which influence company's profit mostly. For example, for an online sales company such indicator is the cost per click and website conversion; for the call-center the most valuable indicator is the duration of operator's calls; for the digital marketing company the most valuable indicator is the quantity of consumers and the average cost of a purchase. Large companies usually have a complex set of indicators, while small businesses may deal with the only one which can be identified as the most significant.

The main idea of this system in terms of motivation is establishing dependence between employee's payment and the set of main indicators of his/her effectiveness. And personal KPI of each employee should be included into the company's KPI. Employee's payment dependent from his/her KPI is divided into two parts: a salary and a variable part. Variable part depends on personal employee's result.

The major positive aspect of KPI is the clear for each employee mechanism of labor assessment and company's operation. When an employee understands 
what amount of money he/she can get by the end of a month, such employee tries to make effort for implementing the plan. The next advantage of KPI is that the management has a tool for adjusting employees' results if they significantly differ from the plan $[2,3]$. And one more positive impact of KPI is a feedback from an employee to a manager and vice versa.

Assuredly along with advantages there are disadvantages of this system. The main minus is possible wrong interpretation of results and, in turn, wrong actions taken for the improvement. For reducing negative influence of this factor it's necessary to define performance indicators and the assessment criteria at the planning stage carefully. It's necessary to mention that implementing KPI system is resource-intensive. First, defining key performance indicators for the whole company and for each employee may take a lot of time. Second, for implementing the KPI system into company business processes it's necessary to instruct and train employees.

The implementation of the KPI system includes the following stages:

1. The identification of strategic company goals. As the KPI system is closely related to the management-by-objectives, identifying both strategic and tactic goals should precede the development of KPIs.

2. The development of KPIs. At this stage the key performance indicators of the whole company, certain departments and certain employees are determined and formed in a system. The obligatory condition is avoiding duplication and gaps. Developing KPIs is a complex process which requires the participation of representatives of all company departments.

3. The allocation of professional duties. Professional duties of an employee should coincide with their KPI. As a result, each KPI should be assigned to a certain person within the organization. Each employee should be responsible for the accomplishment of 3-5 KPIs.

4. The readjustment of business-processes.

5. The development of a new motivation system based on the KPI.

6. The launch.

7. Control and adjustment.

There are three main principles of the KPI system development:

1. Each performance indicator should be measurable.

2. Each performance indicator should be related to the company's operating results.

3. Measurement of a result shouldn't be costly.

The implementation of the KPI system is rather stressful for employees, because they may decide that this system is created for reducing their payments. Thus, the top-management of a company has to explain the mechanism and reasons of implementing the new system as well as the opportunities which employees can get.

Let us consider the example of implementing the KPI system in the pharmacy chain "Viktoriya Region":

1. The following goals were determined as the strategic ones: increasing profit by $10 \%$, business expansion by ten new pharmacies in three years. According to these strategic goals the tactic ones were determined.

2. Certain KPIs were developed for the head office, for each pharmacy and for each employee respectively. For example, the pharmaceutics' KPIs are the 
amount of sales, the average purchase amount, the interaction with the consumer, the quantity of delayed goods, and the accomplishment of a standard. There are planned values of indicators which are set individually for a certain pharmacy. Actual values are compared with the planned ones by the end of each week, half a month, month, quarter and year. Each KPI is assigned an index.

3. Each KPI is matched with professional duties. For example, KPI "the interaction with a consumer" is matched with the duties "the accomplishment of a service standard".

4. The readjustment affected practically all business-processes.

5. According to the new motivation system, each employee gets a fixed salary and a variable part which depends on the personal KPI. Some employees are satisfied by the new system, because their revenues significantly increased due to the over fulfillment of the KPI. Some employees find it difficult to accomplish the planned values. In such cases the analysis is carried out for defining whether the planned values are relevant or not.

In three years the goals have been fully achieved. Thus, the KPI system was implemented effectively.

In conclusion, the KPI system is a complex system which has lots of pitfalls, nevertheless it's an effective tool for improving the motivation system and raising the effectiveness of a business.

\section{References}

1. https://dictionary.cambridge.org/dictionary/english/key-performance-indicator ?q=key-performance- (accessed 11 January 2019).

2. http://fb.ru/article/141427/kpis-chto-eto-kpi-klyuchevyie-pokazateli-effektivnostirazrabotka-kpi (accessed 22 February 2019).

3. Gubanenkova A.P. Sovremennyye tendentsii razvitiya menedzhmenta $i$ gosudarstvennogo upravleniya: materialy zaochnoy Vserossiyskoy nauchnoprakticheskoy konferentsii [Modern tendencies in the development of management and public administration: materials of the correspondence All-Russian Scientific Practical Conference], 21 November, 2017, Orel, 2017, pp. 17-18. (In Russ.)

4. Kurtidi N.R. [Evaluation of the effectiveness of the use of a motivation system based on key performance indicators for enterprises of the military-industrial complex], Ekonomika i biznes: teoriya i praktika [Economics and Business: Theory and Practice], 2018, no. 10-2, pp. 5-10, doi: 10.24411/2411-0450-2018-10076 (In Russ.)

\section{Список литературы}

1. Meaning of key performance indicator in English [Электронный ресурс] // Cambridge Dictionary. - Режим доступа : https://dictionary.cambridge.org/dictionary/ english/key-performance-indicator?q=key-performance (дата обращения: 11.01.2019).

2. KPIs - что это? KPI - ключевые показатели эффективности. Разработка KPI [Электронный ресурс] // Онлайн-журнал FB.ru. - Режим доступа : http://fb.ru/ article/141427/kpis-chto-eto-kpi-klyuchevyie-pokazateli-effektivnosti-razrabotka-kpi (дата обращения: 22.02.2019)

3. Губаненкова, А. П. Внедрение ключевых показателей эффективности как фактор повышения эффективности деятельности организации / А. П. Губаненкова // Современные тенденции развития менеджмента и государственного управления : материалы заочной Всероссийской науч.-практ. конф., 21 ноября 2017 г., Орел. Орел, 2017. - С. $17-18$. 
4. Куртиди, Н. Р. Оценка эффективности применения системы мотивации на базе ключевых показателей эффективности для предприятий обороннопромышленного комплекса / Н. Р. Куртиди // Экономика и бизнес: теория и практика. - 2018. - № 10-2. - C. 5 - 10. doi: 10.24411/2411-0450-2018-10076

\section{Ключевые показатели эффективности как основа построения эффективной системы мотивации персонала}

\section{Е. С. Мищенко, М. С. Лукьяненко}

ФГБОУ ВО «Тамбовский государственный технический университет», г. Тамбов, Россия

Ключевые слова: ключевые показатели эффективности; КРI; система мотивации персонала; стратегические цели компании.

Аннотация: Дано описание проблем компаний, связанных с разработкой и внедрением системы мотивации персонала. Приведены примеры внедрения дополнительных инструментов повышения лояльности персонала. Определено понятие ключевых показателей эффективности, описана взаимосвязь системы КРI и стратегических целей компании. Рассмотрен алгоритм внедрения системы ключевых показателей эффективности (KPI) в бизнес-процессы организации. Рассмотрены основные достоинства и недостатки внедрения системы KPI. Приведены основные этапы и принципы внедрения системы КРI. Рассмотрены основные проблемы, с которыми сталкиваются организации в процессе внедрения системы KPI. Описаны особенности построения системы мотивации персонала, основанной на использовании ключевых показателей эффективности. Рассмотрен опыт внедрения системы KРI в сеть аптек «Виктория Регион». Приведены основные этапы внедрения системы KРI: определение стратегических целей; разработка системы ключевых показателей эффективности для сети аптек в целом, отдельной аптеки и отдельного сотрудника компании; распределение должностных обязанностей в зависимости от КРI; корректировка бизнес-процессов; разработка новой системы мотивации персонала; внедрение системы КРI; контроль и корректировка результатов. Определены стратегические цели сети аптек «Виктория Регион», на основе которых была разработана система ключевых показателей эффективности. Приведены ключевые показатели эффективности фармацевта сети. Описан механизм определения заработной платы. Дана оценка эффективности внедрения системы КРІ.

(C) Е. С. Мищенко, М. С. Лукьяненко, 2019 